\title{
Health and Economic Impacts of Corona and Corona-Related Lockdown on India
}

\author{
J. Cyril Kanmony \\ HOD of Economics (Retd) \& Emeritus Professor, Scott Christian College (Autonomous), Nagercoil, India.
}

\begin{abstract}
How to cite this paper: J. Cyril Kanmony. (2020) Health and Economic Impacts of Corona and Corona-Related Lockdown on India. International Journal of Clinical and Experimental Medicine Research, 4(3), 79-82.

DOI: 10.26855/ijcemr.2020.07.009

Received: June 10, 2020

Accepted: July 5, 2020

Published: July 14, 2020

*Corresponding author: J. Cyril Kanmony, HOD of Economics (Retd) \& Emeritus Professor, Scott Christian College (Autonomous), Nagercoil, India.

Email: cyrilkanmony@ymail.com
\end{abstract}

\begin{abstract}
Occurrence of pandemics is not new to the world. In the world, four pandemics have occurred recently. They are: Spanish flu (1918), Asian flu (1957), Hong Kong flu (1968), and Swine flu (2009). The origin of three of the four pandemics, apart from the "Black Death" that occurred in 1347 is China. The present corona virus has also emerged from China. It threatens all Homo sapiens as it is spreading at a very high speed. It spread to all countries of the world within three months. In India, though deaths are not much high, the number of infected persons is high. To contain its spread, lockdown was announced on the 25th of March 2020. During the lockdown, every engine of growth has stopped firing. And so India's GDP is expected to reach a very low growth rate in 2020-21. The job loss is estimated between 122 and 200 millions. It resulted in the loss of livelihood to millions and a rise in poverty rate. As there was no work for migrant labourers, thousands of them tried to move to their native states by walk. It resulted in many deaths. Thus, the health and the economic impacts of corona on India are very serious.
\end{abstract}

\section{Keywords}

Pandemic, Healthcare, Poverty, Unemployment, Migrant labourers

\section{Introduction}

Occurrence of pandemics is not new to the world. In the world, four pandemics have occurred recently. Long before, i.e., in 1347, a bacteria-caused pandemic called "Black Death" occurred and killed about one third of the world population. All the recently occurred pandemics are called "zoonotic diseases" as they are caused by infections spreading from animals/birds to humans. They are: Spanish flu, Asian flu, Hong Kong flu, and Swine flu. Spanish flu occurred in China during 1918 and killed 50 million people (2.8\% of the world population) and the host animal was waterfowl. It was contained in 1920. Asian flu's, 1957-1958, death tolls were 1.5 million and the host animal was pig. The origination of the flu was also China. The host animal of the Hong Kong flu was also pig. Its period of infection was 1968-1970 and its death toll was 2 million. Swine flu occurred in Mexico, 2009-10, killed 0.58 million people and the host animal was pig. Thus, the origin of three of the four pandemics is China. This present corona virus has also emerged from China. An important fact of this virus is that it is not an entirely new one. It is one of the viruses that have created havoc among people earlier. SARS (Severe Acute Respiratory Syndrome), a strain of corona virus, attacked Southern China and 23 other countries in November 2002 and death toll of it was 800 against the infection number of 8,000. It was contained in July 2003. Another strain of corona virus called MERS (Middle East Respiratory Syndrome) attacked Saudi Arabia in 2013-14. It travelled across 27 countries, infected 2,400 and killed 912 people [1]. But the reproduction number of the present corona virus is very high in comparison with other viruses or strains of corona virus. The mean reproduction number of it is 2.6 (It may go up to 4.08) while it is only 1.0 for MERS and 2.0 for SARS. As it is similar in many respects to SARS, it is also called 
SARS-CoV-2. It was declared by the WHO as a Public Health Emergency of International Concern (PHEIC) on the 30th January 2020 [2]. Its global threat level was upgraded to "very high" on the 28th February 2020 and on the 10th of March, it was announced as a pandemic and named as COVID-19 by the WHO. It threatens all Homo sapiens as it is spreading at a very high speed. Though Wuhan's health authorities alerted the outbreak of the virus to the WHO only on the 31st of December 2019, it spread to all the countries of the world within three months. Hence all the countries that affected much by COVID-19 announced a lockdown. The lockdown completely stopped abruptly the functioning of all economic activities. It results in a livelihood loss to millions of people. Hence, it is the bounden duty of researchers to assess its impact on the people and the economy.

\section{Materials and Methods}

This article made use of only secondary data. The relevant data required for presentation and analysis were collected only from journals and Newspapers. Data are presented mostly in the collected form to substantiate arguments. Very rarely percentages are calculated for analyzing data. The study is exploratory in nature. It tries to highlight the health impact of corona infection and the economic impact of corona-related lockdown on India.

\section{Results and Discussion}

Health Impact: In India, the first case was reported from Kerala in January 2020. After that, it spread quickly and covered all the States of India. As of 8:00 pm on July 9, corona virus infection is 767,296, the third place at the global level immediately after the US and Brazil and the total number of deaths is 21,129. The test positivity rate increased from 4.6\% in mid-March 2020 to $6.73 \%$ as on July 6, 2020 [3]. India's rise in infected cases is the third fastest at the global level [4] though its recovery rate is as high as $62.09 \%$ and the death rate is as low as 2.75\% (globally the respective rates are $58.19 \%$ and $4.53 \%$ ). In India, there is paucity of healthcare facilities. Governments, both the centre and States, are taking various efforts to enhance healthcare facilities. However, the facilities available are not enough to meet the sudden surge in demand. Hence, common people suffer like anything; in some cities, people are running from pillar to post for getting treatment. In private hospitals, the treatment cost is very high. Though some State governments announced caps for both testing and treatment, most of the private hospitals charge an exorbitant rate. It forced most of the poor and the marginalized to knock the door of government hospitals, where there is scarcity of beds and basic facilities such as water and sanitation [5].

Economic Impact: To control the spread of corona virus, the Indian government announced one by one four lockdowns (5th and 6th are not taken into account) from the 25th of March to 31st May 2020. Due to the lockdown, the entire economic activity was brought to halt all of a sudden. Before the lockdown, all engines of growth were firing while during the lockdown every engine of growth has stopped firing. At the beginning, in some states, even the movement of people was completely stopped. Trillion rupees worth of agricultural goods were perished. By the implementation of the lockdown totally 7.4 lakh tonnes of vegetables belonging to roadside vendors were destroyed and the livelihood of nearly 3 million persons was abolished [6]. After a few days, certain essential activities such as agriculture were exempted from lockdown. As for as labourers are concerned during the lockdown they had no works to do and there was no money in their pockets. People like casual and migrant labourers are the worst affected. According to the survey conducted by the Azim Premji University, nearly $84 \%$ of self-employed, $81 \%$ of casual and $76 \%$ regular salaried workers in urban areas and $47 \%$ self-employed, $66 \%$ casual and $62 \%$ regular salary workers in rural areas were not working during the lockdown in comparison with the month of February 2020. In comparison with the income earned in February, there was a fall by $50 \%$ in rural areas and $46 \%$ in urban areas for casual labourers and a fall of 92\% in rural areas and $86 \%$ in urban areas for self-employed non-agricultural workers. The percentage of workers whose wage payment was delayed or their wage was reduced was $43 \%$ in rural areas and $57 \%$ in urban areas. Hence, there was a fall in the consumption of goods and services. About $74 \%$ of the respondents consumed less food during the lockdown than the pre-lockdown period [7]. The CMIE reported that the overall labour participation rate declined from $42 \%$ to $36.1 \%$ within a period of two weeks [8]. Due to all these and a very high corona-related treatment cost many families were pushed into poverty. The population below the poverty line increased from 560 million before the lockdown to 960 million after the lockdown. The rate of extreme poverty (daily expense of 30 rupees per person or less) increased from $16 \%$ before the lockdown to $42 \%$ after the lockdown [9].

The average employment declined from 396 million in March 2020 to 282 million in April 2020. The overall unemployment rate reached an all time high of 27.1 in May 2020. The number of job loss increased to 122 million (of them 91.3 million are small traders and labourers) in April 2020 from only about 30 million in 2018 [10]. But Kumar put it at 200 million as only $25 \%$ of the economy was working and nearly $94 \%$ of the employment was 
provided by the unorganized sector [11]. The sale of passenger vehicles saw a fall of $85 \%$ in May 2020 in comparison with May 2019. The fall in output of core sector is estimated at 38\% and merchandise export decreased by 60\% in April 2020 in comparison with the same month in the previous year. The first time in Indian history manufacturing sector witnessed a fall in jobs after 2012. The tertiary sector is also in shatters. The output loss to India is estimated at $\$ 190$ billion within 47 days of lockdown, (Globally a loss of $\$ 8.5$ trillion as per a recent UNO report) [12]. The growth rate of GDP was 8\%-9\% before the world financial crisis, 2008 [13]. But for the year 2020-'21, it is estimated between a negative growth rate of $6 \%$ and a positive growth rate of just $1 \%$ [14]. As per the modified advanced revised estimate of CSO, the growth rate was only $2.94 \%$ against $4.2 \%$ for the year 2019-'20. The Fitch estimated it at only $0.8 \%$ and the International Monetary Fund at $1.9 \%$ [15]. The Bombay Stock Exchange Index almost halved, from above 40,000 to around 20,000 at the beginning of May 2020. ATM cash withdrawals almost halved from 2.51 million crore (crore $=$ ten million) rupees in March 2020 to 1.28 million crore rupees in April 2020 [16]. The public debt rate to GDP increased from 72\% to 84\% [17]. There was also a sharp fall in revenue collection of all entities and workers. The GST collection of the central government contracted by $41 \%$ in the first quarter of the financial year 2020-'21 in comparison with the first quarter of the previous financial year, i.e., from 0.31 million crore to 0.19 million crore rupees. The GST collection was only 32,294 crore in April 2020 against the collection of 110,818 crore rupees in January 2020, a crash of 72\% [18].

As there was no economic activity during the first three lockdowns, there was no work for labourers, particularly migrant labourers. Hence, they moved to their native villages. The size of the total number of internal migrants is estimated at 450 million as per the 2011 Census against only 309 million in 2001, an increase of 45\%. During this period the population growth was only $18 \%$. As a percentage to total population, the proportion of migrated population increased from 30\% in 2001 to $37 \%$ in 2011 [19]. The life of migrants was not protected, food was not ensured and even drinking water was not supplied to many. They are being treated as irritants. After a long period of wait, 50 days, millions of them tried to move to their native places, thousands of miles, by walk. A few migrant labourers were killed in accidents on their ways, a few died because of stress and a few because of starvation. The heart breaking migrant crisis is compared with migration of people at the time of India's partition in 1947. At present governments are arranging special trains, Shramik. But a total of 80 persons died while travelling in Shramik trains between May 9 and May 27 and there have been more than 850 non-COVID deaths due to the lockdown [20]. The process of reverse migration will result in the presence of more people in agriculture, expected to increase by 5.2 million within a short period. It really takes the Indian economy 15 years back [21]. All these forced the central government to announce a relief package of 20 lakh crore rupees. However the virus has not yet contained and the recovery has not yet started.

\section{References}

[1] Gupta, Alok. (2020). Coronavirus Panic. Down To Earth. $16^{\text {th }}$ February, pp. 30-46.

[2] Lindmeir, Christian. (2020). We Need to Address the Unknown. Down To Earth. $16^{\text {th }}$ February, p. 46.

[3] Official updates coronavirus-COVID-19 in India-my gov.in. (2020). retrieved at 8:00om on 9 $9^{\text {th }}$ July 2020 \& Editorial. Vigilance paramount, The Hindu, $23^{\text {rd }}$ June, p. 6.

[4] Special Correspondent. (2020). India's rise in cases third fastest globally, The Hindu, $15^{\text {th }}$ June, p. 1.

[5] Kanmony, J. Cyril. (2017). Public Healthcare Sector: Is It Losing Its Importance in the Rural Tamil Nadu, Review of Public Administration and Management, January, 5, 1, pp. 1-9.

[6] Sampath, G. (2020). Ideas for the $19^{\text {th }}$ tranche of relief, The Hindu Magazine, $9^{\text {th }}$ May, p. 06.

[7] Data Point. (2020). Massive job losses, The Hindu, $13^{\text {th }}$ May, p. 7.

[8] Data Point. (2020). Locked down \& out of work, The Hindu, $8^{\text {th }}$ May, p. 7.

[9] Special Correspondent. (2020). GST revenues plunge $41 \%$ in first quarter, The Hindu, $2^{\text {nd }}$ July, p. 1.

[10] Data Point. (2020). Job loss mounts, The Hindu, $7^{\text {th }}$ May, p. 7.

[11] Kumar, Arun. (2020). Can India's workforce have a safe return to business, The Hindu, 26 $6^{\text {th }}$ May, p. 10.

[12] Shah, Nilesh. (2020). In SC, Economy to see output loss of $\$ 190 \mathrm{bn}$, The Hindu, $10^{\text {th }}$ May, p. 10.

[13] Mehrotra, Santosh. (2020). Reverse migration to villages has set the economy back by 15 years, The Hindu, $27^{\text {th }}$ May, p. 5.

[14] Singh, N. K. (2020). In SC, finance panel flags recovery uncertainty, The Hindu, $22^{\text {nd }}$ May, p. 19.

[15] Rangarajan, C. and D. K. Srivastava. (2020). Slower growth and a tighter fiscal, The Hindu, $9^{\text {th }}$ May, p. 6.

[16] Saha, Manojit. (2020). ATM cash withdrawals halved in April, The Hindu, $12^{\text {th }}$ June, p. 13.

[17] Mohan, T. T. Ram. (2020). Who's afraid of monetisation of deficit? The Hindu, $9^{\text {th }}$ June, p. 6. 
[18] Mazumdar, Sumit and Indranil. (2020). Rolling back to induced livelihood shock, The Hindu, $7^{\text {th }}$ July, p. 11.

[19] Hazarika, Sanjoy. (2020). The echo of migrant foot falls at the silence on policy, The Hindu, $28^{\text {th }}$ May, p. 6.

[20] Narayanan, Rajendran. (2020). The pandemic is about eyes shut, The Hindu, $9^{\text {th }}$ July, p. 6.

[21] Mehrotra, Santosh. (2020). Reverse migration to villages has set the economy back by 15 years, The Hindu, $27^{\text {th }}$ May, p. 5. 